\title{
KEMAMPUAN KOMUNIKASI MATEMATIS DALAM PEMBELAJARAN MENGGUNAKAN GOOGLE CLASSROOM DITINJAU DARI SELF CONFIDENCE PESERTA DIDIK
}

\author{
Nazhifah Nurul Zalfa ${ }^{1}$, Ibnu Sina ${ }^{2}$, M. Shaefur Rokhman ${ }^{3}$ \\ Program Studi Pendidikan Matematika Universitas Pancasakti Tegal ${ }^{1,2,3}$ \\ nazhifah63@gmail.com ${ }^{1}$
}

\begin{abstract}
ABSTRAK
Penelitian ini memiliki tujuan untuk : (1) menganalisis kemampuan komunikasi matematis tertulis dalam pembelajaran yang menggunakan google classroom ditinjau dari self confidence peserta didik dan (2) menganalisis kemampuan komunikasi matematis lisan dalam pembelajaran yang menggunakan google classroom ditinjau dari self confidence peserta didik pada materi statistika kelas VIII E SMP Negeri 5 Adiwerna. Metode yang digunakan pada penelitian ini adalah metode deskriptif kualitatif. Pengumpulan data yang digunakan adalah menggunakan angket untuk mendapatkan data self confidence, tes dan wawancara untuk mendapatkan data kemampuan komunikasi matematis peserta didik. Hasil analisis penelitian menunjukkan bahwa : 1) kemampuan komunikasi matematis tulis peserta didik dengan self confidence tinggi memenuhi empat indikator kemampuan komunikasi matematis, subjek dengan self cofidence sedang hanya memenuhi tiga indikator kemampuan komunikasi tulis, dan subjek dengan self confidence rendah hanya memenuhi satu indikator kemampuan komunikasi. 2) kemampuan komunikasi matematis lisan peserta didik dengan self confidence tinggi memenuhi empat indikator kemampuan komunikasi matematis, subjek dengan self cofidence sedang hanya memenuhi tiga indikator kemampuan komunikasi lisan dan subjek dengan self confidence rendah hanya memenuhi dua indikator kemampuan komunikasi lisan.
\end{abstract}

Kata kunci : komunikasi, google classroom, self confidence

\begin{abstract}
The goals of this study are to: (1) examine written mathematical communication skills in learning using Google Classroom in terms of students' self-confidence, and (2) examine verbal mathematical communication skills in learning using Google Classroom in terms of students' self-confidence in statistical material at VII E class SMP Negeri 5 Adiwerna. The qualitative descriptive method was used in this study. A questionnaire was used to collect data on self-confidence, and tests and interviews were used to collect data on students' mathematical communication skills. The study's findings show that: 1) students with high selfconfidence meet four indicators of mathematical communication skills, subjects with moderate self-confidence meet three indicators of written communication skills, and subjects with low self-confidence meet one indicator of communication skills, 2) students with high self-confidence have four indicators of mathematical communication skills, subjects with moderate self-confidence have three indicators of oral communication skills, and subjects with low selfconfidence have two indicator of oral communication skills.
\end{abstract}

Keywords : communication, google classroom, self confidence 


\section{PENDAHULUAN}

Matematika merupakan ilmu yang saling berhubungan serta sebagian dari materinya berlandaskan pada perhitungan, matematika adalah salah satu mata pelajaran yang ada dalam semua jenjang pendidikan, dimulai dari sekolah dasar hingga perguruan tinggi (Mustikasari et al., 2017).

Proses pembelajaran yakni aktivitas saat pendidikan secara komprehensif yang mengikutsertakan guru serta peserta didik pada sebuah interaksi edukatif yang menopang dalam mencapai tujuan khusus. Komunikasi adalah bagian esensial dari proses pembelajaran dikarenakan sebagai dasar untuk mengembangkan pemahaman peserta didik (Majid, 2020).

Kemampuan komunikasi peserta didik ini sangat penting dalam pembelajaran sehingga dalam pembelajaran matematika ini peserta didik dapat mengembangkan pemahaman konsep yang mereka miliki, kemampuan komunikasi matematis tidak hanya mengenai lisan tetapi juga dengan tulisan, oleh karena itu kemampuan komunikasi ini perlu dikembangkan sejak dini. Menurut Lestari dan Yudhanegara (2015:83) kemampuan komunikasi matematis yakni keterampilan mengemukakan pikiran matematis dalam lisan atau tulis, juga keterampilan untuk secara cermat, analitis, dan kritis menilai, memahami, serta menerima ide/gagasan matematis orang lain dalam rangka mempertajam pemahaman.

Susanto (Safitri, 2018) mengemukakan bahwa komunikasi matematis bisa diartikan berupa kegiatan percakapan maupun hubungan timbal balik di lingkungan kelas dimana informasi disampaikan, serta informasi yang dikirim berisi materi matematika yang dikaji peserta didik, seperti konsep, rumus, maupun metode pemecahan kasus melalui pertukaran informasi lisan atau tertulis. Adapun indikator kemampuan komunikasi matematis menurut Ritonga (2018) yaitu : (1) Keterampilan untuk menggabungkan objek nyata menjadi gagasan matematika. (2) Mampu mengungkapkan pikiran matematis secara tertulis dan mengungkapkan kejadian sehari-hari dengan lambang-lambang matematika. (3) Kemampuan menggunakan gambar untuk memaparkangagasan, kondisi sehari-hari, serta hubungan matematis dalam bentuk tulisan. (4) Keterampilan dalam mencerna serta meninjau gagasan matematis ketika menyelesaikan kasus sehari-hari dengan tulisan. (5) Mampu menyampaikan kesimpulan pada jawaban pertanyaan sehari-hari berdasarkan hasil pertanyaan.

Selain kemampuan komunikasi matematisnya peserta didik perlu belajar dengan self confidence yang dimilikinya. Menurut Taylor (Wahyuni, 2019) selfconfidence adalah keyakinan individu dengan kemampuan yang dia punya guna menunjukkan perilaku tertentu ataupun guna meraih sasaran tertentu. Individu yang mempunyai rasa percaya diri, akan sanggup menunjukkan kelebihan yang dia miliki dengan perilaku pada kehidupannya. Dengan adanya self confidence yang ada pada diri peserta didik maka peserta didik dengan mudah dapat mengkomunikasikan ide mereka untuk menyelesaikan suatu masalah.

Menurut Syam dan Amri (2017) tingkat kepercayaan diri bisa dipengaruhi oleh keterampilan serta kemampuan yang dikuasai. Peserta didik yang memiliki rasa percaya diri tinggi dapat dengan mudah berinteraksi dengan peserta didik lain, akan sanggup mengungkapkan pendapatnya dengan yakinserta akan menghargai opini peserta didik lainnya, sanggup bertindak serta berpikir positif saat mengambil langkah. Di sisi lain, peserta didik yang kurang percaya diri merasa susah 
berkomunikasi, beropini, serta merasa tidak bisa bersaing dengan peserta didik lainnya

Pada kenyataannya rasa percaya diri peserta didik berbeda-beda, yang bisa dilihat ketika proses pembelajaran berlangsung, ketika diminta mengungkapkan pendapat ada peserta didik yang dengan berani mengungkapkan apa yang ada di pikirannya di hadapan teman serta gurunya, ada peserta didik yang ragu ketika berbicara di depan kelas, lalu ada juga peserta didik yang diam ketika ditunjuk gurunya agar maju ke depan kelas.

Adapun indikator self confidence menurut Lauster (Hendriana, et al., 2014) yaitu : (1) Percaya pada keterampilan diri, tidak takut bertindak, bebas serta bertanggung jawab saat melaksanakan hal-hal yang dia sukai, (2) mandiri dalam pengambilan keputusan, (3) saat berinteraksi dengan orang lain, memiliki citra diri yang positif, antusias, dan sopan serta mampu menerima serta menghargai individu lain, (4) berani menyampaikan opini serta mempunyai motivasi untuk berprestasi, (5) memahami kelebihan serta kekurangan diri sendiri.

Berdasarkan hasil wawancara dengan salah satu guru matematika diperoleh bahwa masih banyak peserta didik di SMP Negeri 5 Adiwerna dalam mengikuti pembelajaran matematika cenderung pasif karena peserta didik mengaggap matematika itu sulit dan kurangnya rasa percaya diri peserta didik dalam menjawab soal matematika. Kemampuan komunikasi matematis peserta didik secara lisan maupun tulisan terbilang rendah, dapat dilihat pada saat pembelajaran berlangsung peserta didik kurang aktif seperti malu untuk bertanya dan peserta didik kurang membaca buku sehingga kemampuan komunikasi matematis peserta didik untuk mengikuti pembelajaran matematika pun sedikit. Masih banyak peserta didik yang belum bisa menyimpulkan dari sebuah soal yang telah dikerjakan. Peserta didik juga masih kurang paham dengan konsep matematika dan kurangnya ketepatan dalam menyebutkan simbol atau notasi matematika.

Dalam kondisi saat ini mengharuskan tiap orang berada di rumah untuk menghambat penyebaran virus Covid-19. Dengan adanya pandemi Covid-19 yang sedang melanda ini, maka Pemerintah mengeluarkan kebijakan yang salah satunya pembelajaran yang pada awalnya bertatap muka lalu digantikan dengan e-learning. Pada SMP Negeri 5 Adiwerna setelah terjadinya pandemi Covid-19 menerapkan kebijakan pemerintah yaitu melakukan pembelajaran e-learning. Salah satu platform pembelajaran yang saat ini digunakan oleh para guru dan peserta didik yaitu google classroom. Google classroom adalah pembelajaran jarak jauh yang dilakukan secara online dimana akan tercipta ruang kelas di dunia maya. Google classroom merupakan salah satu aplikasi pembelajaran secara online atau e-learning yang dapat digunakan oleh guru dan peserta didik di masa pandemi covid-19. Google classroom memiliki banyak fitur di dalamnya seperti penugasan, quis, penilaian dan lain-lain.

Sesuai dengan latar belakang di atas, maka dilakukan analisis bagaimana kemampuan komunikasi matematis peserta didik kelas VIII E SMP Negeri 5 Adiwerna ditinjau dari self confidence ketika digunakan google classroom dalam pembelajarannya.

\section{METODE}

Jenis penelitian ini penelitian kualitatif yang bersifat deskriptif. Subjek penelitian ini adalah 6 orang siswa kelas VIII E SMP Negeri 5 Adiwerna tahun Pelajaran 2020/2021. Pengambilan subjek pada penelitian ini melalui hasil angket 
self confidence peserta didik yang sudah dikategorikan sesuai dengan tingkat self confidence yaitu self confidence tinggi, self confidence sedang, dan self confidence rendah.

Teknik pengumpulan data yang digunakan adalah: 1) angket self confidence yang digunakan untuk mengukur tingkat kepercayaan peserta didik, 2) tes kemampuan komunikasi matematis yang digunakan untuk mengukur kemampuan komunikasi matematis tertulis peserta didik, dan 3) wawancara yang digunakan untuk mengukur kemampuan komunikasi matematis peserta didik secara lisan.

Teknik analisis data pada penelitian ini yaitu: 1) menghitung skor dari angket self confidence dimana subjek akan dikategorikan tinggi, sedang, dan rendah lalu mencari nilai rata-rata atau mean dan simpangan baku atau standar deviasi untuk mencari subjek dengan kategori tinggi, sedang, dan rendah, 2) analisis deskriptif pada jawaban tes kemampuan komunikasi matematis peserta didik, 3) wawancara untuk memperkuat jawaban dari peserta didik mengenai kemampuan komunikasi matematis.

Indikator self confidence yang digunakan yaitu menurut Lauster (Triana, 2020) yang terdiri dari 5 indikator, yaitu: (1) Percaya pada keterampilan diri, tidak takut bertindak, bebas serta bertanggung jawab saat melaksanakan hal-hal yang dia sukai, (2) Mandiri dalam pengambilan keputusan, (3) Saat berinteraksi dengan orang lain, memiliki citra diri yang positif, antusias, dan sopan serta mampu menerima serta menghargai individu lain, (4) Berani menyampaikan opini serta mempunyai motivasi untuk berprestasi, dan (5) Memahami kelebihan serta kekurangan diri sendiri.

Indikator kemampuan komunikasi matematis yang diacu menurut Ritonga (2018) yaitu : (1) Keterampilan untuk menggabungkan objek nyata menjadi gagasan matematika. Dalam penelitian ini, peserta didik bisa menuliskan informasi yang dipahami serta menarik tujuan pertanyaan tersebut, (2) Mampu mengungkapkan pikiran matematis secara tertulis dan mengungkapkan kejadian sehari-hari dengan lambang-lambang matematika. Dalam penelitian ini, peserta didik bisa memakai simbol matematika ketika menulis informasi masalah dan memecahkan masalah, (3) Kemampuan menggunakan gambar untuk memaparkan gagasan, kondisi sehari-hari, serta hubungan matematis dalam bentuk tulisan. Dalam penelitian ini, peserta didik sanggup menggambarkan tabel, (4) Keterampilan dalam mencerna serta meninjau gagasan matematis ketika menyelesaikan kasus sehari-hari dengan tulisan. Dalam penelitian ini, peserta didik bisa menuliskan konsep rumus yang dipakai pada saat mengerjakan kasus, bisa memakai langkah penyelesaian secara baik dan mampu melaksanakan perhitungan secara benar, (5) Mampu menyampaikan kesimpulan pada jawaban pertanyaan sehari-hari berdasarkan hasil pertanyaan. Dalam penelitian ini, peserta didik bisa mencatat kesimpulan dari solusi sesuai dengan tujuan pertanyaan.

\section{HASIL DAN PEMBAHASAN}

Penelitian ini dilakukan pada peserta didik kelas VIII E SMP Negeri 5 Adiwerna yang diikuti oleh 31 peserta didik dengan memberikan soal materi statistika dan angket self confidence. Pemberian soal dan angket diupload pada google classroom yang sebelumnya dibuat kelas online di google classroom dan lembar jawab soal tes dan angket peserta didik dapat dikirim melalui google classroom. Dari hasil analisis tersebut diambil masing-masing 2 subjek dari setiap 
kategori self confdence. Berikut merupakan hasil angket self confidence peserta didik kelas VIII E.

Tabel 1. Hasil angket self confidence

\begin{tabular}{cc}
\hline Rata-rata $(\bar{x})$ & 42,16 \\
\hline Standar Deviasi (SD) & 4,9 \\
\hline $\bar{x}+S D$ & 46,25 \\
\hline $\bar{x}-S D$ & 38,10
\end{tabular}

Berdasarkan hasil angket tersebut peserta didik dibagi menjadi 3 kategori yaitu : peserta didik dengan self confidence tinggi, peserta didik dengan self confidence sedang, dan peserta didik dengan self confidence rendah.

Tabel 2. Pembagian kategori self confidence

\begin{tabular}{cc}
\hline Self confidence tinggi & $x \geq 46,25$ \\
\hline Self confidence sedang & $38,10<x<46,25$ \\
\hline Self confidence rendah & $x \leq 38,10$ \\
\hline
\end{tabular}

Dari hasil angket yang telah dikategorikan didapat 6 peserta didik dengan self confidence tinggi, 21 peserta didik dengan self confidence sedang, dan 4 peserta didik dengan self confidence rendah.

Tabel 3. Daftar subjek penelitian

\begin{tabular}{ccc}
\hline Kode nama & $\begin{array}{c}\text { Pengelompokan } \\
\text { self confidence }\end{array}$ & Kode subjek \\
\hline D-10 & Tinggi & T-1 \\
D-30 & Tinggi & T-2 \\
\hline D-25 & Sedang & S-1 \\
D-29 & Sedang & S-2 \\
\hline D-8 & Rendah & R-1 \\
D-15 & Rendah & R-1 \\
\hline
\end{tabular}

Berdasarkan dari tabel 3 selanjutnya dilakukan analisis hasil tes kemampuan komunikasi matematis dan dilakukannya wawancara sesuai dengan subjek yang telah ditentukan. Untuk analisis kemampuan komunikasi matematis peserta didik dikategorikan yaitu kemampuan komunikasi matematis tinggi, kemampuan komunikasi matematis sedang, dan kemampuan komunikasi matematis rendah.

$\underline{\text { Soal tes kemampuan komunikasi matematis }}$

Disajikan sebuah data profesi sejumlah wali siswa di SMP Mahir

i. Guru : 25 wali siswa

ii. Pedagang : 35 wali siswa

iii. Karyawan : 50 wali siswa

iv. TNI/Polri : 15 wali siswa 


\section{v. Petani : 30 wali siswa}

a. Buatlah diagram batang dari data tersebut dan tentukan jumlah seluruh wali siswa di SMP Mahir!

b. Tentukan profesi paling banyak dari wali siswa!

c. Tentukan selisih banyak wali siswa yang berprofesi sebagai karyawan dan guru!

\section{a) Kemampuan Komunikasi Matematis Peserta Didik dengan Self Confidence Tinggi}

Peserta didik yang memiliki self confidence tinggi memenuhi 4 indikator kemampuan komunikasi matematis. Hal ini ditunjukkan ketika mengerjakan soal tes subjek dapat mengerjakan dengan baik, tidak dengan sikap yang ragu-ragu dan optimis. Selaras dengan penelitian Muniroh, et al. (2018) semakin tinggi self confidence peserta didik maka semakin tinggi juga kemampuan komunikasi matematisnya. Penelitian yang dilakukan Akbar (Aussieanna, 2020) menyatakan peserta didik dengan self confidence tinggi pasti dalam mengerjakan soal, dapat menjawab dan berani untuk bertanya kepada guru. Sesuai dengan penelitian Noviyana, et al. (2019) peserta didik yang memiliki kemampuan komunikasi yang baik jika ia memiliki self yang baik, hal tersebut disebabkan oleh pandangan positif yang dimiliki peserta didik terhadap kemampuan dirinya sehingga ia tidak merasa takut atau cemas saat menyelesaikan masalah.

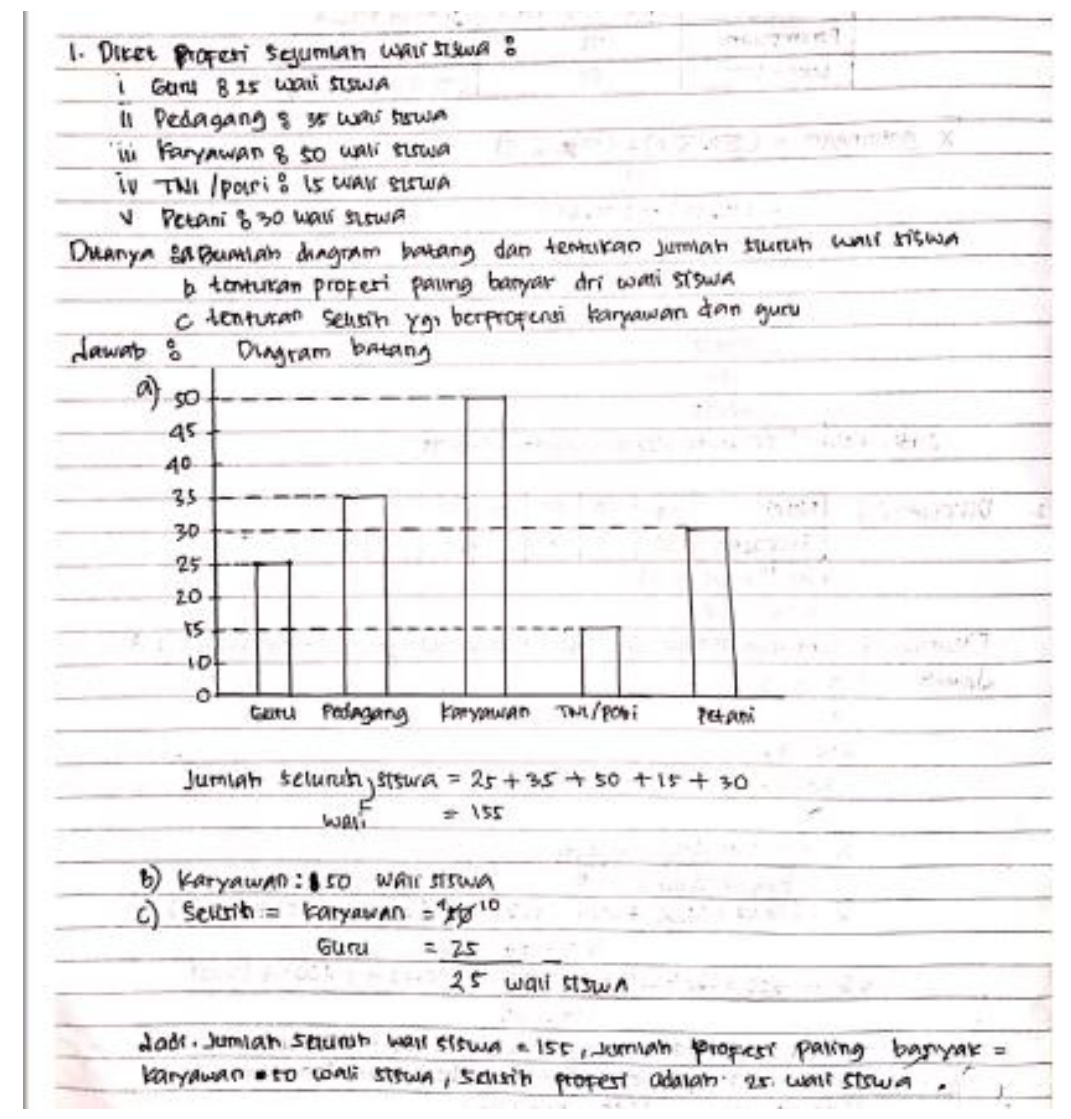

Gambar 1. Hasil tes kemampuan komunikasi matematis peserta didik dengan self confidence tinggi 
Dari hasil analisis kemampuan komunikasi pada hasil tes subjek tinggi bahwa subjek tinggi dapat memenuhi indikator 1 yang ditunjukkan dengan mencantumkan informasi yang diketahui serta informasi yang ditanyakan pada soal, dapat memenuhi indikator 3 yaitu sanggup menggambarkan diagram batang dan menggambar tabel sesuai dengan data yang telah disajikan, memenuhi pula indikator 4 yaitu mampu mencantumkan rumus yang digunakan dalam penyelesaian pada soal, dapat menggunakan langkah-langkah penyelesaian dengan tepat dan benar dan mampu memenuhi indikator 5 yaitu mampu mencantumkan kesimpulan sesuai dengan permasalahan yang ditanyakan pada soal. Sehingga dapat disimpulkan bahwa subjek dengan self confidence tinggi mampu memenuhi 4 indikator kemampuan komunikasi matematis.

\section{b) Kemampuan Komunikasi Matematis Peserta Didik dengan Self Confidence Sedang}

Peserta didik yang memiliki self confidence sedang memenuhi 3 indikator kemampuan komunikasi matematis. Untuk subjek dengan kemampuan komunikasi matematis sedang sedikit merasa bingung dan kurang optimis dalam menjawab soal tes, dapat dilihat dari jawaban tes dan jawaban wawancara subjek. Menurut penelitian Jahani dan Behzadi (Rizqi, et al., 2016) seseorang dapat dikatakan mempunyai kepercayaan diri apabila ia memiliki keyakinan akan kemampuan yang dimiliki dalam mengatasi permasalahan. Sehingga dalam menghadapi permasalahan, siswa yang mempunyai rasa percaya diri sedang maupun tinggi dapat mengungkapkan ide-ide matematis melalui lisan dan tulisan, menggambarkan ide-ide matematis dalam bentuk visual, dan menggunakan notasi dan istilah matematis untuk menyajikan ide-ide matematis dengan baik.

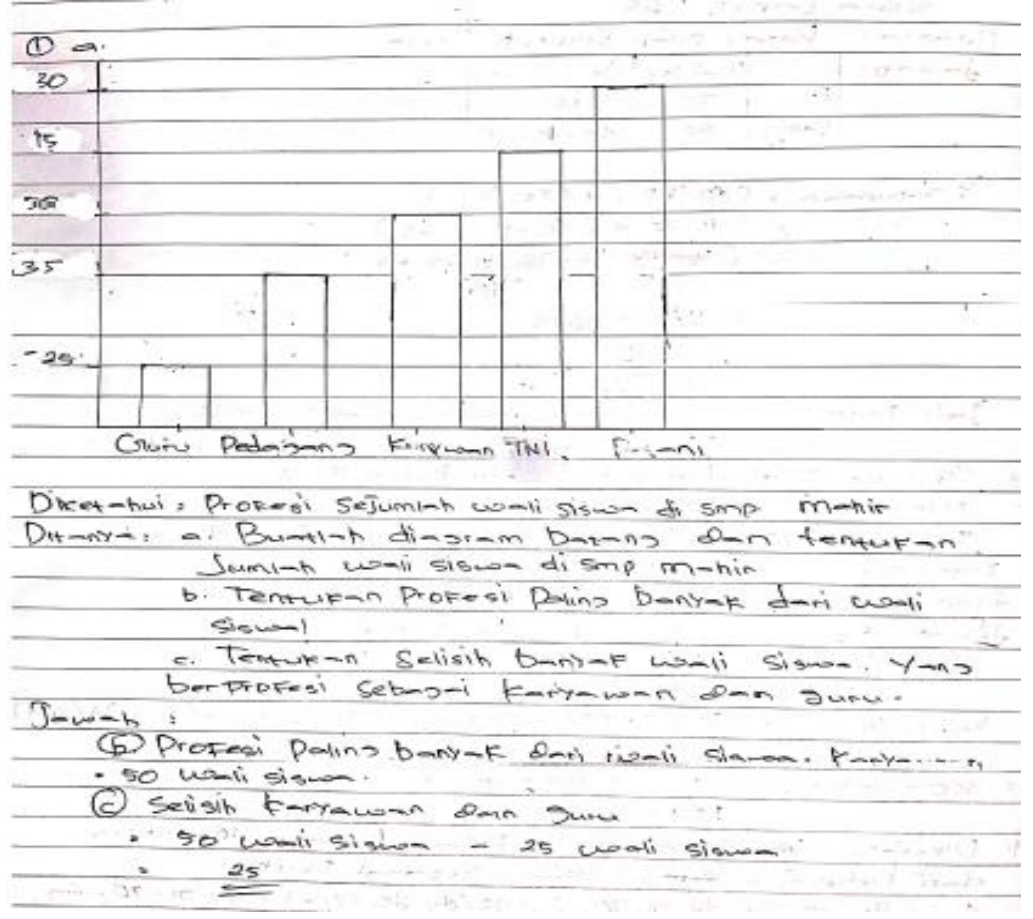

Gambar 2. Hasil tes kemampuan komunikasi matematis peserta didik dengan self confidence sedang 
Dari hasil analisis kemampuan komunikasi pada subjek sedang bahwa subjek sedang dalam indikator 1 mampu menuliskan informasi yang diketahui dan yang ditanyakan pada soal, lalu pada indikator 3 subjek sanggup menggambarkan diagram batang dan menggambar tabel sesuai dengan data yang telah disajikan, memenuhi pula indikator 4 yaitu mampu mencantumkan rumus yang digunakan dalam penyelesaian pada soal, dapat menggunakan langkah-langkah penyelesaian dengan tepat dan benar. Sehingga dapat disimpulkan bahwa subjek dengan self confidence sedang dapat memenuhi 3 indikator kemampuan komunikasi matematis.

\section{c) Kemampuan Komunikasi Matematis Peserta Didik dengan Self Confidence Rendah}

Peserta didik yang memiliki self confidence rendah memenuhi 1 indikator kemampuan komunikasi matematis. Subjek ini merasa ragu-ragu ketika menjawab tes kemampuan komunikasi matematis dan merasa malu ketika ditanya mengenai soal tes kemampuan komunikasi matematis. Sesuai dengan penelitian yang dilakukan Subekti dan Kusuma (2016) peserta didik dengan self confidence rendah belum dapat memenuhi semua indikator kemampuan komunikasi matematis. Selaras dengan Swallow (Rahayuningdyah, 2016) kepercayaan diri peserta didik yang rendah dikarenakan kurangnya berkomunikasi dengan teman bicaranya, kurangnya minat peserta didik dalam melakukan berbagai hal, dan menghindari lawan bicara serta memperlihatkan sikap pemarahnya.

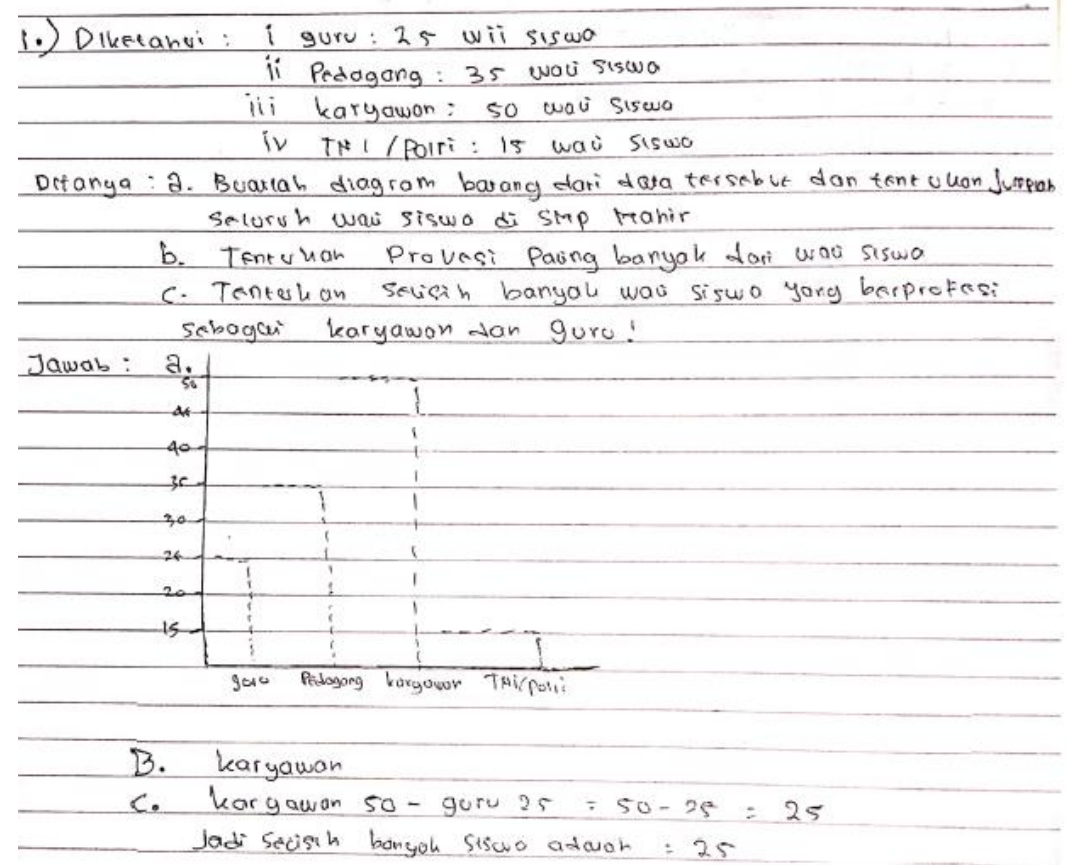

Gambar 3. Hasil tes kemampuan komunikasi matematis peserta didik dengan self confidence rendah

Dari hasil analisis kemampuan komunikasi pada subjek rendah bahwa subjek rendah dalam indikator 1 mampu menuliskan informasi yang diketahui dan yang ditanyakan pada soal, lalu pada indikator 3 subjek sanggup menggambarkan diagram batang dan menggambar tabel sesuai dengan data yang telah disajikan. Sehingga 
dapat disimpulkan bahwa untuk subjek dengan self confidence rendah dapat memenuhi 2 indikator kemampuan komunikasi matematis.

\section{d) Hasil Wawancara Peserta Didik dengan Self Confidence Tinggi}

Dari hasil wawancara yang dilakukan, bahwa subjek dengan self confidence tinggi pada indikator 1 mampu mengungkapkan dan menjelaskan informasi yang diketahui dengan lengkap dan mampu menjelaskan informasi yang ditanyakan pada soal, pada indikator 3 kemampuan komunikasi matematis lisannya subjek tinggi mampu memenuhi indikator yang ditunjukkan pada saat wawancara bahwa subjek tinggi dapat menjelaskan bagaimana ia menggambar diagram batang, lalu pada indikator 4 dapat memenuhi yang ditunjukkan pada saat wawancara bahwa subjek tinggi dapat menjelaskan rumus-rumus yang digunakan untuk penyelesaian soal dan ia dapat menjelaskan urutan langkah-langkah yang tepat dan benar dalam penyelesaian soal, dan pada indikator 5 yang ditunjukkan pada saat wawancara bahwa subjek tinggi dapat menjelaskan kesimpulan yang ditanyakan pada soal meskipun dalam membuat kesimpulan subjek tinggi tidak menggunakan bahasanya sendiri melainkan mengikuti yang ditanyakan pada soal. Sehingga dapat disimpulkan untuk hasil wawancara pada peserta didik dengan self confidence tinggi dapat memenuhi 4 indikator kemampuan komunikasi matematis.

\section{e) Hasil Wawancara Peserta Didik dengan Self Confidence Sedang}

Dari hasil wawancara yang dilakukan, bahwa subjek dengan self confidence sedang pada indikator 1 yang ditunjukkan pada saat wawancara bahwa subjek sedang dapat menjelaskan informasi yang diketahui dan informasi yang ditanyakan pada soal, pada indikator 3 yang ditunjukkan pada saat wawancara bahwa subjek sedang dapat menjelaskan bagaimana ia menggambar diagram batang dan menggambar tabel, dan subjek sedang mampu memenuhi indikator 4 ditunjukkan pada saat wawancara bahwa subjek sedang dapat menjelaskan rumus-rumus yang digunakan untuk penyelesaian soal dan ia dapat menjelaskan urutan langkah-langkah yang tepat dan benar dalam penyelesaian soal. Sehingga dapat disimpulkan untuk hasil wawancara pada peserta didik dengan self confidence sedang dapat memenuhi 3 indikator kemampuan komunikasi matematis.

\section{f) Hasil Wawancara Peserta Didik dengan Self Confidence Rendah}

Dari hasil wawancara yang dilakukan, bahwa subjek dengan self confidence rendah pada indikator 1 yang ditunjukkan pada saat wawancara bahwa subjek rendah dapat menjelaskan informasi yang diketahui dan informasi yang ditanyakan pada soal, pada indikator 3 yang ditunjukkan pada saat wawancara bahwa subjek rendah dapat menjelaskan bagaimana ia menggambar diagram batang. Sehingga dapat disimpulkan untuk hasil wawancara pada peserta didik dengan self confidence rendah dapat memenuhi 2 indikator kemampuan komunikasi matematis.

\section{SIMPULAN DAN SARAN}

Berdasarkan hasil penelitian dan pembahasan yang telah dilakukan didapat simpulan sebagai berikut : (1) Peserta didik dengan self confidence tinggi memenuhi 4 indikator kemampuan komunikasi matematis yaitu keterampilan untuk menggabungkan objek nyata menjadi gagasan matematika, kemampuan membuat gambar untuk memaparkan gagasan kondisi sehari-hari serta hubungan matematis 
dalam bentuk tulisan dan lisan, kondisi sehari-hari serta hubungan matematis dalam bentuk tulisan, keterampilan mencerna serta meninjau gagasan matematis ketika menyelesaikan kasus sehari-hari dengan tulisan dan lisan, dan mampu menyampaikan kesimpulan pada jawaban pertanyaan sehari-hari berdasarkan hasil pertanyaan. (2) Peseta didik dengan self confidence sedang memenuhi 3 indikator kemampuan komunikasi matematis yaitu keterampilan untuk menggabungkan objek nyata menjadi gagasan matematika, kemampuan membuat gambar untuk memaparkan gagasan, kondisi sehari-hari serta hubungan matematis dalam bentuk tulisan dan lisan, Keterampilan dalam mencerna serta meninjau gagasan matematis ketika menyelesaikan kasus sehari-hari dengan tulisan dan lisan. (3) Peserta didik dengan self confidence rendah hanya memenuhi 1 indikator yaitu kemampuan membuat gambar untuk memaparkan gagasan, kondisi sehari-hari, serta hubungan matematis dalam bentuk tulisan dan lisan.

Berdasarkan hasil penelitian ini guru hendaknya membantu peserta didik dalam pembelajaran matematika yang membutuhkan penerapan komunikasi matematis serta membuat peserta didik lebih percaya diri lagi dalam pembelajaran. Guru hendaknya meminta peserta didik agar lebih teliti lagi ketika mengerjakan soal.

\section{DAFTAR PUSTAKA}

Aussieanna, S. R. 2020. Kemampuan Komunikasi Matematis Siswa Kelas X SMA Ditinjau dari Self-Confidence. Naskah Publikasi : 1-13. Tersedia: http://eprints.ums.ac.id/82839/13/NASKAH\%20PUBLIKASI\%20SHAFIRA.p df

Hendriana, H., Slamet, U.R., and Sumarmo, U. 2014. Mathematical Connection Ability and Self-Confidence (An Experiment on Junior High School Students Through Contextual Teaching and Learning with Mathematical Manipulative). International Journal of Education, Vol. 8(1) : 1-11.

Lestari, K. E., dan Yudhanegara, M. R. 2015. Penelitian Pendidikan Matematika. Bandung: Refika Aditama.

Majid, R. N. 2020. Analisis Kemampuan Komunikasi Matematis Peserta Didik dalam Pembelajaran Menggunakan Daring. Skripsi tidak diterbitkan. Tegal: Universitas Pancasakti Tegal.

Muniroh, S., Rosyana, T., dan Hendriana, H. 2018. Hubungan Self-Cofidence dengan Kemampuan Komunikasi Matematik Siswa SMP. JPMI (Jurnal Pembelajaran Matematika Inovatif), Vol. 1(4) : 479-486.

Mustikasari, M., Isnani, dan Susongko, P. 2017. Keefektifan Model Pembelajaran Talking Stick Berbantu Media Microsoft Power Point Terhadap Prestasi Belajar Matematika Ditinjau dari Kemampuan Numerik Materi Pokok Statistika. Jurnal Pendidikan MIPA Pancasakti, Vol. 1(1) : 65-71.

Noviyana, I. N., Dewi, N. R., dan Rochmad. 2019. Analisis Kemampuan Komunikasi Matematis Siswa Ditinjau dari Self-Confidence. PRISMA, Prosiding Seminar Nasional Matematika, Vol. 2, 704-709. Tersedia: https://journal.unnes.ac.id/sju/index.php/prisma/article/view/29241

Rahayuningdyah, E. 2016. Upaya Meningkatkan Kepercayaan Diri Melalui Layanan Konseling Kelompok pada Siswa Kelas VIII D di SMP Negeri 3 Ngrambe. Jurnal JIPE, Vol. 1(2) : 1-14.

Ritonga, S. N. 2018. Analisis Kemampuan Komunikasi Matematis Siswa dalam Pembelajaran Matematika MTs Hifdzil Qur'an Medan Tahun Ajaran 
2017/2018. Skripsi tidak diterbitkan. Medan: Universitas Islam Negeri Sumatera Utara.

Rizqi, A. A., Suyitno, H., dan Sudarmin. 2016. Analisis Kemampuan Komunikasi Matematis Ditinjau Dari Kepercayaan Diri Siswa Melalui Blended Learning. Unnes Journal of Mathematics Education Research, Vol. 5(1) : 17-23.

Safitri, A. 2018. Efektivitas Pembelajaran Berbasis Proyek Terhadap Kemampuan Komunikasi Matematis Peserta Didik Kelas VIII MTS Negeri 1 Jepara Pada Materi Bangun Ruang Sisi Datar Tahun Pelajaran 2017/2018. Skripsi tidak diterbitkan. Semarang: Universitas Islam Negeri Walisongo.

Subekti, F. E., dan Kusuma, A. B. 2016. Deskripsi Kemampuan Komunikasi Matematis Ditinjau dari Rasa Percaya Diri Mahasiswa. Euclid, Vol. 3(1) : 430446.

Syam, A. dan Amri. 2017. Pengaruh Kepercayaan Diri (Self Confidence) Berbasis Kaderisasi IMM Terhadap Prestasi Belajar Mahasiswa (Studi Kasus di Program Studi Pendidikan Biologi Fakultas Keguruan dan Ilmu Pendidikan Universitas Muhammadiyah Parepare). Jurnal Biotek, Vol. 5(1) : 87-102.

Triana, C. R. 2020. Analisis Kemampuan Komunikasi Matematis Siswa SMP Ditinjau dari Self Confidence Siswa Pada Materi Lingkaran. Skripsi tidak diterbitkan. Pekanbaru: Universitas Islam Negeri Sultan Syarif Kasim Riau.

Wahyuni, T. 2019. Pengaruh Model Pembelajaran Aptitude Treatment Interaction (ATI) Ditinjau Dari Self Confidence Terhadap Pemahaman Konsep Matematis Peserta Didik. Skripsi tidak diterbitkan. Lampung: Universitas Islam Negeri Raden Intan. 